\title{
DESAIN DAN UJI COBA LEMBAR KERJA PESERTA DIDIK (LKPD) BERBASIS PROBING-PROMPTING PADA MATERI SISTEM PERIODIK UNSUR
}

\author{
Rini Karsini, Pangoloan Soleman Ritonga \\ Program Studi Pendidikan Kimia Fakultas Tarbiyah dan Keguruan Universitas Islam Negeri Sultan Syarif \\ Kasim Riau, Jl. H.R. Soebrantas No.155 KM.15 Simpang Baru Panam Pekanbaru, Indonesia
}

Coressponding author: rini.karsini@students.uin-suska.ac.id

\begin{abstract}
Abstrak
Penelitian ini dilatarbelakangi penguasaan kimia peserta didik dalam pembelajaran masih rendah, khususnya untuk materi konsep/teori yang bersifat abstrak. Hal ini terlihat dari peserta didik kurang aktif dan kurang daya ingat dalam mengikuti proses pembelajaran. Selain itu, sekolah hanya mengandalkan buku paket yang membuat peserta didik kurang tertarik dalam belajar serta belum terdapat LKPD untuk menunjang pemahaman peserta didik. Penelitian ini bertujuan untuk mengetahui kelayakan desain media pembelajaran berupa Lembar Kerja Peserta Didik (LKPD) berbasis probing-prompting pada materi sistem periodik unsur. Penelitian ini dilaksanakan di MAN 1 Pekanbaru. Metode penelitian yang digunakan adalah Research and Development dengan model 4-D (4-D Models), yang dibatasi menjadi model 3 tahap yaitu: Define (pendefinisian), Design (perencanaan), Development (pengembangan). Subjek penelitian ini adalah ahli materi, ahli media, ahli bahasa, guru kimia, dan 10 orang peserta didik kelas X MIA 1. Sedangkan objek penelitian ini adalah LKPD berbasis probing-prompting pada materi sistem periodik unsur. Hasil penelitian yang diperoleh menunjukkan bahwa LKPD berbasis probing-prompting layak digunakan berdasarkan hasil dari tingkat kevalidan dan tingkat kepraktisan. Persentase tingkat kevalidan yang diperoleh sebesar $85.78 \%$ (sangat valid) dan tingkat kepraktisan $85.33 \%$ (sangat praktis). Dari hasil tersebut mengidentifikasikan bahwa LKPD berbasis probing-prompting dapat diuji cobakan lebih lanjut.
\end{abstract}

\section{Kata kunci}

Lembar Kerja Peserta Didik(LKPD), Probing-Prompting, Sistem Periodik Unsur

\begin{abstract}
This research is motivated by students' chemical mastery in learning is still low, especially for abstract concept/theory material. This can be seen from students being less active and lacking memory in following the learning process. In addition, schools only rely on textbooks that make students less interested in learning and there is no student workbook to support students' understanding. The purpose of this research was for knowing the appropriateness of the instructional media design in the form of Probing-Prompting based student workbook on Periodic System of the Elements lesson. It was $R \& D$ (Research and Development) with 4-D model, and it was limited to 3 models - define, design, and development. The subjects of this research were the experts of material, the experts of media, and the experts of language, Chemistry teachers, 10 students at the tenth grade of MIA 1. The object was Probing-Prompting based student workbook on Periodic System of the Elements lesson. The research findings showed that Probing-Prompting based student workbook was appropriate to be used and it was based on the results of validity and practicality levels. The percentage of validity level obtained was $85.78 \%$ (very valid) and the practicality level was $85.33 \%$ (very practical). Based on these results, it could be identified that the LKPD probingprompting-based can be tested further.
\end{abstract}

\section{Keywords}

Student Workbook, Probing-Prompting, Periodic System of the Element 


\section{Pendahuluan}

Menurut Undang-Undang Nomor 14 tahun 2015 guru berkualitas adalah guru yang memiliki kompetensi pedagogik, kompetensi kepribadian, kompetensi sosial, dan kompetensi professional. Dalam melaksanakan kompetensi pedagogik, secara metodologis dalam perencanaan dan pelaksanaan pembelajaran, termasuk penguasaan dalam penggunaan media pembelajaran [1]. Sebagai pendidik, diharapkan mampu mendesain suatu media pembelajaran yang menarik agar peserta didik termotivasi untuk belajar. Media pembelajaran tersebut ialah bahan ajar berupa modul, Lembar Kerja Peserta Didik (LKPD), handout, buku paket, dan berbagai informasi yang dapat diakses melalui elektronik atau internet.

Lembar Kerja Peserta Didik (LKPD) adalah lembaran-lembaran berisi tugas yang harus dikerjakan oleh peserta didik.Depdiknas menjelaskan keuntungan penggunaan LKPD ialah dapat mempermudah guru dalam pembelajaran dan membiasakan peserta didik untuk belajar secara mandiri serta memahami dan menjelaskan tugas secara tertulis [2].

Pengembangan LKPD diharapkan dapat dijadikan sebagai sumber belajar siswa, agar dapat memperoleh bahan dan sekaligus arahan maupun motivasi, sehingga mengalami proses pemahaman konsep.Pengembangan LKPD tersebut didukung dengan suatu pendekatan, model, maupun teknik pembelajaran yang sesuai. Salah satu alternatif model pembelajaran yang mengupayakan siswa untuk aktif dalam membangun dan memahami materi pelajaran adalah model Probing-Prompting [3]. Menurut Suherman, Pembelajaran probing prompting adalah pembelajaran dengan menyajikan serangkaian pertanyaan yang sifatnya menuntun dan menggali gagasan peserta didik, sehingga dapat terjadi proses berpikir yang mampu mengaitkan pengetahuan dan pengalamannya dengan pengetahuan yang baru dipelajari [4].

Kelebihan model pembelajaran Probing Prompting antara lain adalah mendorong peserta didik aktif berfikir, memberi kesempatan kepada peserta didik untuk menanyakan hal-hal yang kurang jelas sehingga guru dapat menjelaskan kembali, perbedaan pendapat antara peserta didik dapat dikompromikan atau diarahkan pada suatu diskusi, pertanyaan dapat menarik dan memusatkan perhatian peserta didik, sekalipun ketika itu peserta didik sedang ribut, yang mengantuk, kembali (review) bahan pelajaran yang lampau, mengembangkan keberanian dan keterampilan peserta didik dalam menjawab dan mengemukakan pendapat [5].

Dari penelitian Fajar, diperoleh informasi bahwa hasil belajar siswa dengan model pembelajaran tanya jawab Probing Prompting lebih tinggi daripada hasil belajar siswa dengan metode pembelajaran ceramah [6], dan Kariani dalam penelitiannya menerapkan model Problem Based Learning dengan menggunakan metode Probing Prompting yang hasilnya berpengaruh terhadap hasil belajar IPA siswa dibandingkan dengan model pembelajaran konvensional [7]. Keberhasilan penelitian di atas menjadi gagasan peneliti untuk menerapkan model pembelajaran Probing-Prompting.

Berdasarkan hasil wawancara, bahwa di sekolah hanya menggunakan buku paket sebagai bahan ajar sehingga kurangnya penguasaan kimia peserta didik dalam pembelajaran kimia, terlihat dari peserta didik yang kurang aktif, kurang daya ingat dalam mengikuti proses pembelajaran, khususnya untuk materi konsep/teori yang bersifat abstrak.

Sistem Periodik Unsur (SPU) merupakan salah satu materi dengan teori dan konsep yang bersifat abstrak. Mungkin tampak mudah, akan tetapi materi ini merupakan materi dasar yang harus dipahami peserta didik, karena akan dipelajari secara berkelanjutan. Misalnya, ikatan kima, jika peserta didik tidak paham tentang sistem periodik unsur, kemungkinan peserta didik tidak akan mengerti apa yang berikatan, kenapa berikatan, dan bagaimana cara berikatan. Karena materi ini bersifat abstrak, maka dibutuhkanlah suatu media pembelajaran yang dapat memvisualisasikan materi tersebut agar mudah dipahami peserta didik salah satunya yaitu Lembar Kerja Peserta Didik (LKPD).Namun, selain memiliki kelebihan, LKPD juga memiliki kekurangan, dimana untuk meminimalisir kekurangan tersebut, maka 
dibutuhkan suatu model pembelajaran, salah satunya yaitu probing-prompting. Berdasarkan uraian yang telah dipaparkan, maka peneliti tertarik untuk melakukan suatu penelitian sebagai upaya dalam melakukan perbaikan terhadap pembelajaran dengan mendesain LKPD berbasis probing-prompting pada materi SPU.

Tujuan penelitian ini adalah untuk mengetahui tingkat kelayakan dan tingkat kemudahan LKPD berbasis probing-prompting pada materi SPU dengan menggunakan tingkat uji validitas dan tingkat uji praktikalitas.

\section{Metode Penelitian}

Jenis penelitian yang dilakukan adalah metode penelitian dan pengembangan (Research and Development).Research and Development (R\&D) adalah metode penelitian yang digunakan untuk menghasilkan produk tertentu dan menguji keefektifan produk tersebut [8]. Penelitian dan pengembangan berfungsi untuk memvalidasi dan mengembangkan produk. Memvalidasi produk, berarti produk itu telah ada, dan peneliti hanya menguji efektivitas atau validitas produk tersebut. Mengembangkan produk dalam arti luas dapat berupa memperbarui produk yang telah ada (sehingga menjadi lebih praktis, efektif, dan efisien) atau menciptakan produk baru (yang sebelumnya belum pernah ada) [9].

Produk penelitian dan pengembangan dalam bidang pendidikan dapat berupa model, media, peralatan, bahan ajar, alat evaluasi, dan perangkat pembelajaran, kurikulum, kebijakan sekolah, dan lain-lain [10]Selanjutnya, model pengembangan dalam penelitian ini adalah model pengembangan $4-D$, akan tetapi hanya dilakukan sampai tahap ketiga yaitu sampai pada pengembangan produk. Hal ini dikarenakan keterbatasan waktu dan biaya penelitian.Peneliti lebih memilih model 4-D, karena model ini lebih mudah dibandingkan dengan model $R \& D$ yang lain, dan pada prinsipnya inti dari prosedur pengembangan produk sudah terwakili disini. Selain itu, model ini sering digunakan dalam penelitian dan pengembangan bahan ajar seperti modul, LKPD dan buku ajar.

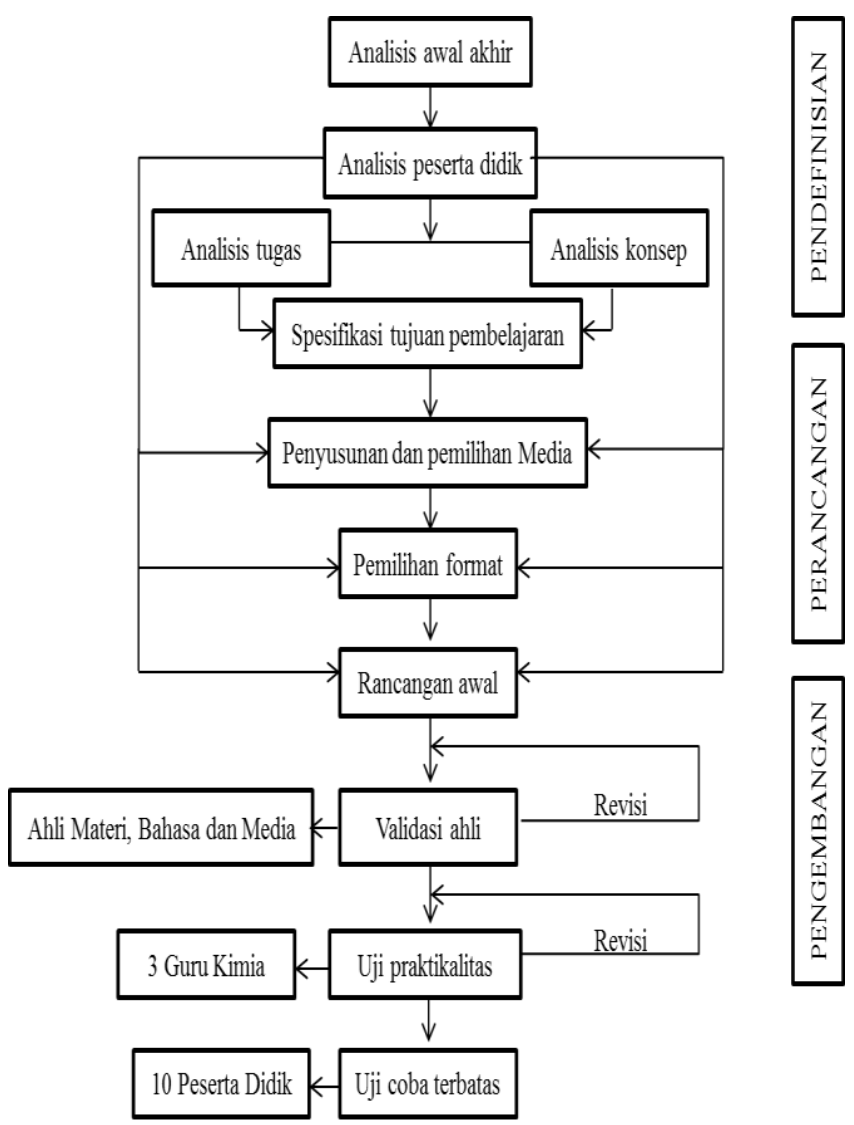

Gambar 1 Prosedur Penelitian

(Sumber: Thiagarajan, Semmel, dan Semmel, 1974)

Penelitian ini dilaksanakan di kelas X MIA 1 Madrasah Aliyah Negeri (MAN) 1 Pekanbaru dan dimulai 5Agustus 2019sampai dengan 31 Agustus 2019 pada semester ganjil Tahun Ajaran 2019/2020. Subjek dalam penelitian ini adalah pihak yang melakukan validasi terhadap produk LKPD yang dihasilkan yaitu ahli desain media, ahli materi, ahli bahasa, dan praktikalitas oleh guru kimia serta respon peserta didikdi MAN 1 Pekanbaru.Sedangkan objek dalam penelitian ini adalah LKPD berbasis probing-promptingpada materi SPU.Teknik pengumpulan data menggunakan wawancara dan angket (kuisioner).

Angket yang digunakan adalah angket uji validitas, uji praktikalitas dan respon peserta didik. Teknik ini dilakukan agar mendapatkan data yang valid untuk media yang telah dirancang sehingga media tersebut layak atau tidak layak untuk digunakan. Penilaian instrumen (angket) untuk ahli media, bahasa dan dan materi, serta guru disusun berdasarkan Badan Standar Nasional Pendidikan (BNSP) tentang penilaian buku teks pelajaran 
kimia Sekolah Menengah Atas/ Madrasah Aliyah [11]. Kemudian, penilaian instrumen untuk guru dan peserta didik, disusun menurut skala penilaian (rating scale). Rating scale yaitu data mentah yang di dapat berupa angka (data kuantitatif) yang ditafsirkan kedalam pengertian kualitatif [12], sehingga penilai akan memilih salah satu jawaban kualitatif yang telah disediakan. Kelebihannya yaitu rating scale lebih fleksibel, tidak saja untuk mengukur sikap tetapi juga bisa digunakan untuk mengukur persepsi responden. Selain itu, skala ini mudah digunakan dan mudah di pahami, serta motode ini juga mudah dibuat dan dimodifikasi jika memang dibutuhkan.

Data penelitian dianalisis dengan analisis kualitatif dan kuantitatif, serta disajikan dalam bentuk deskriptif. Data ntuk tahap pendefinisian dan perancangan dianalisis secara kualitatif. Data tahap dari tahap pengembangan, yakni validitas dan praktikalitas dianalisis secara kuantitatif.

Analisis hasil uji validitas LKPD berbasis probing prompting dilakukan beberapa langkah, yaitu:

a) Menentukan jumlah skor tertinggi

Tabel 1 Skor Penilaian terhadap Pilihan Jawaban

\begin{tabular}{ccccccccccc}
$\begin{array}{c}\text { Alternatif } \\
\text { Penilaian }\end{array}$ & $\begin{array}{l}\text { Kurang } \\
\text { Sekali }\end{array}$ & Kurang & & Baik & \multicolumn{3}{c}{$\begin{array}{l}\text { Baik } \\
\text { Sekali }\end{array}$} \\
\hline Skala & 1 & 2 & 3 & 4 & 5 & 6 & 7 & 8 & 9 & 10 \\
\hline
\end{tabular}

\section{Skor tertinggi $=$ jumlah validator $\times$ jumlah item} $\times$ skor maksimum

b) Menentukan skor yang diperoleh dengan menjumlahkan skor dari masing-masing validator.

c) Pemberian nilai persentasi dengan cara:

$$
\text { Nilai Validitas }=\frac{\text { jumlah skor yang diperoleh }}{\text { jumlah skor tertinggi }} \times 100 \%
$$

Setelah persentase diperoleh, dilakukan pengelompokkan sesuai kriteria yang dimodifikasi dari Riduwan pada tabel 2.

Tabel 2 Interpretasi Data Validitas LKPD

\begin{tabular}{lll}
\hline No. & Interval & Kriteria \\
\hline
\end{tabular}

\begin{tabular}{ccc}
\hline 1 & $81 \%-100 \%$ & Sangat valid \\
2 & $61 \%-80 \%$ & Valid \\
3 & $41 \%-60 \%$ & Cukup valid \\
4 & $21 \%-40 \%$ & Kurang valid \\
5 & $0 \%-20 \%$ & Tidak valid \\
\hline
\end{tabular}

Sedangkan analisis hasil uji praktikalitas LKPD berbasis probing prompting dilakukan beberapa langkah, yaitu:

a) Menentukan jumlah skor tertinggi

Tabel 3 Skor Penilaian terhadap Pilihan Jawaban

\begin{tabular}{ccccccccccc}
\hline $\begin{array}{c}\text { Alternatif } \\
\text { Penilaian }\end{array}$ & $\begin{array}{c}\text { Kurang } \\
\text { Sekali }\end{array}$ & Kurang & & Baik & $\begin{array}{c}\text { Baik } \\
\text { Sekali }\end{array}$ \\
\hline Skala & 1 & 2 & 3 & 4 & 5 & 6 & 7 & 8 & 9 & 10 \\
\hline
\end{tabular}

Skor tertinggi $=$ jumlah guru $\times$ jumlah item $\times$ skor maksimum

b) Menentukan skor yang diperoleh dengan menjumlahkan skor dari masing-masing validator.

c) Pemberian nilai persentasi dengan cara:

Nilai Validitas $=\frac{\text { jumlah skor yang diperoleh }}{\text { jumlah skor tertinggi }} \times 100 \%$

Setelah persentase diperoleh, dilakukan pengelompokkan sesuai kriteria yang dimodifikasi dari Riduwan pada tabel 4.

Tabel 4 Interpretasi Data Praktikalitas LKPD

\begin{tabular}{ccc}
\hline No. & Interval & Kriteria \\
\hline 1 & $81 \%-100 \%$ & Sangat praktis \\
2 & $61 \%-80 \%$ & Praktis \\
3 & $41 \%-60 \%$ & Cukup praktis \\
4 & $21 \%-40 \%$ & Kurang praktis \\
5 & $0 \%-20 \%$ & Tidak praktis \\
\hline
\end{tabular}

\section{Hasil dan Pembahasan}

Penelitian ini menghasilkan produk berupa Lembar Kerja Peserta Didik (LKPD) berbasis probing-prompting pada materi sistem periodik unsur, yang telah di uji validitas dan praktikalitas, agar mengetahui kelayakan dan kepraktisan dari produk tersebut sebelum diuji cobakan. LKPD ini disusun berdasarkan kompetensi inti dan kompetensi dasar yang terdapat didalam Peraturan Menteri Pendidikan Kebudayaan 
(PerMenDikBud) Republik Indonesia Nomor 37 Tahun 2018.

Penelitian ini menggunakan prosedur pengembangan model pengembangan $4-D$ yang telah dibatasi sampai tahap ketiga, dikarenakan keterbatasan waktu dan biaya penelitian. Tahap pertama yang dilakukan adalah pendefinisian (Define), yaitu menetapkan dan mendefinisikan syarat-syarat pembelajaran. Dalam menentukan dan menetapkan syarat-syarat pembelajaran diawali dengan analisis ujung depan (awal akhir), analisis peserta didik, analisis tugas, analisis konsep, dan perumusan tujuan pembelajaran. Sehingga dapat dibatasi batasan materi yang dikembangkan, produk apa yang akan dikembangkan, beserta spesifikasinya. Menurut Ikhsanudin menyatakan bahwa kimia merupakan salah satu pelajaran yang dianggap sukar dipahami oleh peserta didik. Hal ini menyebabkan peserta didik kurang tertarik dalam mempelajari ilmu kimia. Agar peserta didik dapat memahami ilmu kimia secara konseptual, dibutuhkan kemampuan untuk mempresentasikan dan menerjemahkan masalah dan fenomena kimia tersebut kedalam bentuk yang mudah dipahami serta membuat peserta didik lebih berperan aktif dalam proses pembelajaran [13]. Sumber belajar dan media pembelajaran yang dapat membantu peserta didik dan guru dalam proses pembelajaran adalah Lembar Kerja Peserta Didik (LKPD). LKPD termasuk media cetak hasil pengembangan teknologi cetak yang berupa buku [14].

Tahap kedua adalah perancangan (Design), berisi kegiatan untuk membuat rancangan terhadap produk yang telah ditetapkan, dari tahap ini terbentuklah penyusunan, pemilihan media, dan rancangan awal berupa LKPD berbasis probingprompting pada materi sistem periodik unsur. Depdiknas menjelaskan keuntungan penggunaan LKPD ialah dapat mempermudah guru dalam pembelajaran dan membiasakan peserta didik untuk belajar secara mandiri serta memahami dan menjalankan tugas secara tertulis. Selanjutnya, Depdiknas menjelaskan bahwa dalam penyusunan LKPD harus memenuhi syarat-syarat didaktik, konstruksi, teknik serta keterandalan dan kesahihan. Syarat didaktik mengatur tentang penggunaan LKPD yang bersifat universal, artinya dapat digunakan dengan baik untuk peserta didik yang lamban atau yang pandai. LKPD lebih menekankan pada proses untuk menemukan konsep. Syarat konstruksi berhubungan dengan penggunaan bahasa, susunan kalimat, kosakata, tingkat kesukaran, dan kejelasan dalam LKPD. Syarat teknis menekankan pada tulisan, gambar, penampilan dalam LKPD [15]. Keterandalan dan kesahihan mempunyai kriteria yang dapat ditinjau dari kemampuan LKPD untuk meningkatkan pemahaman konsep dan keterampilan (kepraktisan).Selain itu, dalam menciptakan proses pembelajaran yang menyenangkan dan berkualitas dibutuhkan strategi dan inovasi yang tepat [16]. Salah satu model pembelajaran yang dapat memberikan keleluasan berpikir kepada peserta didik adalah model pembelajaran sifatnya menuntun dan menggali pengetahuan peserta didik dan pengalamannya dengan pengetahuan yang baru dipelajari yaitu probing-prompting [17]. Probing-prompting merupakan salah satu teknik bertanya yang efektif dalam menuntun proses berpikir peserta didik, sehingga peserta didik dapat menemukan sendiri pengetahuan yang ingin dicapai [18]. Hasil penelitian Roza menyatakan penerapan model pembelajaran dapat meningkatkan keaktifan peserta didik dan hasil belajar pada mata pelajaran kimia.

Tahap ketiga adalah pengembangan (Development), setelah terbentuk rancangan awal LKPD, dilakukan uji validitas oleh para pakar secara berulang-ulang sampai dihasilkan produk sesuai dengan spesifikasi yang ditetapkan. Kemudian di uji praktikalitas oleh guru kimia dan uji coba ke 10 orang peserta didik.

\section{a. Tahap Pendefinisian (Define)}

1) Analisis Awal Akhir (Kurikulum)

Kurikulum merupakan suatu rencana tertulis yang disusun guna memperlancar proses pembelajaran. Hal ini sesuai dengan undang-undang nomor 20 tahun 2003, tentang pendidkan nasional bahwa kurikulum adalah seperangkat rencana dan pengaturan mengenai tujuan, isi, dan bahan pelajaran serta cara yang digunakan sebagai pedoman penyelenggaraan kegiatan pembelajaran untuk mencapai pendidikan tertentu. Kurikulum 
berfungsi sebagai pedoman dalam melaksanakan proses kegiatan belajar mengajar [19].

Kurikulum yang saat ini digunakan dikenal dengan Kurikulum 2013. Dalam Kurikulum 2013 dijabarkan Kompetensi Inti (KI) dan Kompetensi Dasar (KD) untuk setiap jenjang pendidikan. Pada analisis ini hanya dijabarkan KI dan KD pada silabus mata pelajaran kimia tingkat MA kelas X semester 1. Hasil yang didapatkan dari tahap ini yaitu materi yang memerlukan LKPD adalah materi Sistem Periodik Unsur, materi ini merupakan materi dasar yang sangat penting untuk memahami pelajaran kimia secara berkelanjutan.

Berdasarkan wawancara yang telah dilakukan terhadap guru, diketahui bahwa sekolah hanya menggunakan buku paket sebagai media pembelajaran. Selain itu, LKPD yang dijual dipasaran masih terkesan monoton (teks bacaan tanpa gambar, berwarna hitam putih), dan dari segi penyajiannya kurang menarik disebabkan gambar dan LKPD tidak berwarna.

\section{2) Analisis Peserta Didik}

Menurut teori Piaget, untuk peserta didik pada rentang usia 11 tahun-dewasa berada pada tahap perkembangan operasi formal, yaitu pemikiran abstrak dan murni simbolis mungkin dilakukan. Dimana remaja mengalami tahap transisi dari penggunaan operasi konkret ke penerapan operasi formal dalam menalar. Remaja mulai menyadari keterbatasan pemikiran mereka, dimana mereka mulai bergelut dengan konsep yang ada diluar pengalaman mereka sendiri [20]. Vygotsky berpendapat seperti Piaget, bahwa peserta didik membentuk pengetahuan sebagai hasil dari pikiran maupun kegiatan itu sendiri melalui bahasa. Teori Vygotsky ini lebih menekankan bahwa fungsi mental yang lebih tinggi pada umumnya muncul dalam percakapan dan kerja sama antar-individu sebelum fungsi mental yang lebih tinggi itu terserap ke dalam invidu tersebut.Hasil analisis peserta didik yang mempelajari Sistem Periodik Unsur dikelas X MIA MA, berkisar pada usia 1517 tahun. Usia tersebut merupakan awal masa pubertas anak kelihatan lebih subjektif, mereka mulai dapat menghargai pendapat orang lain karena menyadari bahwa orang lain pun mempunyai hak yang sama.

Selain itu, teori perkembangan Piaget mewakili teori konstruktivisme. Menurut teori konstruktivisme ini, satu prinsip yang paling penting dalam psikologi pendidikan adalah bahwa guru tidak hanya sekadar memberikan pengetahuan kepada peserta didik. Peserta didik harus membangun sendiri pengetahuan di dalam benaknya. Guru dapat memberikan kemudahan untuk proses ini dengan memberi kesempatan peserta didik untuk menemukan atau menerapkan ide-ide mereka sendiri. Guru dapat memberi peserta didik anak tangga yang membawa peserta didik ke pemahaman yang lebih tinggi, dengan catatan peserta didik sendiri yang harus memanjat anak tangga tersebut. Hal ini LKPD didesain dengan model probing-prompting, dimana peserta didik diberi beberapa pertanyaan yang menggali untuk melatih pengetahuan mereka. Setelah menjawab pertanyaan, mereka akan menanggapi dan mempresentasikan dari hasil yang mereka kerjakan. Selain itu, LKPD juga didesain semenarik mungkin dengan berbagai paduan warna dan gambar agar memotivasi peserta didik untuk lebih tertarik membaca dan mengerjakan kegiatan-kegiatan didalamnya.

\section{3) Analisis Tugas}

Analisis tugas adalah kumpulan prosedur untuk menentukan isi dalam satuan pembelajaran. Analisis tugas ini dilakukan untuk memerinci isi materi ajar dalam bentuk garis besar. Hasil analisis ini LKPD didesain sedemikian rupa dengan model probing-prompting.

\section{4) Analisis Konsep}

Analisis konsep merupakan identifikasi konsep utama yang akan diajarkan dan menyusunnya secara sistematis serta mengaitkan satu konsep dengan konsep lain yang relevan, sehingga membentuk suatu peta konsep.

5) Spesifikasi Tujuan Pembelajaran

Penyusunan tujuan pembelajaran atau indikator pencapaian hasil belajar didasarkan pada Kompetensi Dasar (KD) dan indikator yang tercantum dalam kurikulum tentang suatu konsep 
materi.Hal ini termuat setiap awal kegiatan dalam LKPD.

b. Tahap Perancangan (Design)

1) Pemilihan Format

Pada tahap ini peneliti merancang LKPD pada materi sistem periodik unsur dengan model probing-prompting.LKPD ini terdiri dari tiga bagian yaitu bagian pendahuluan, bagian isi, dan bagian penutup.

2) Perancangan Awal

Tabel 5 Deskripsi Prototipe LKPD berbasis probingprompting pada Materi SPU

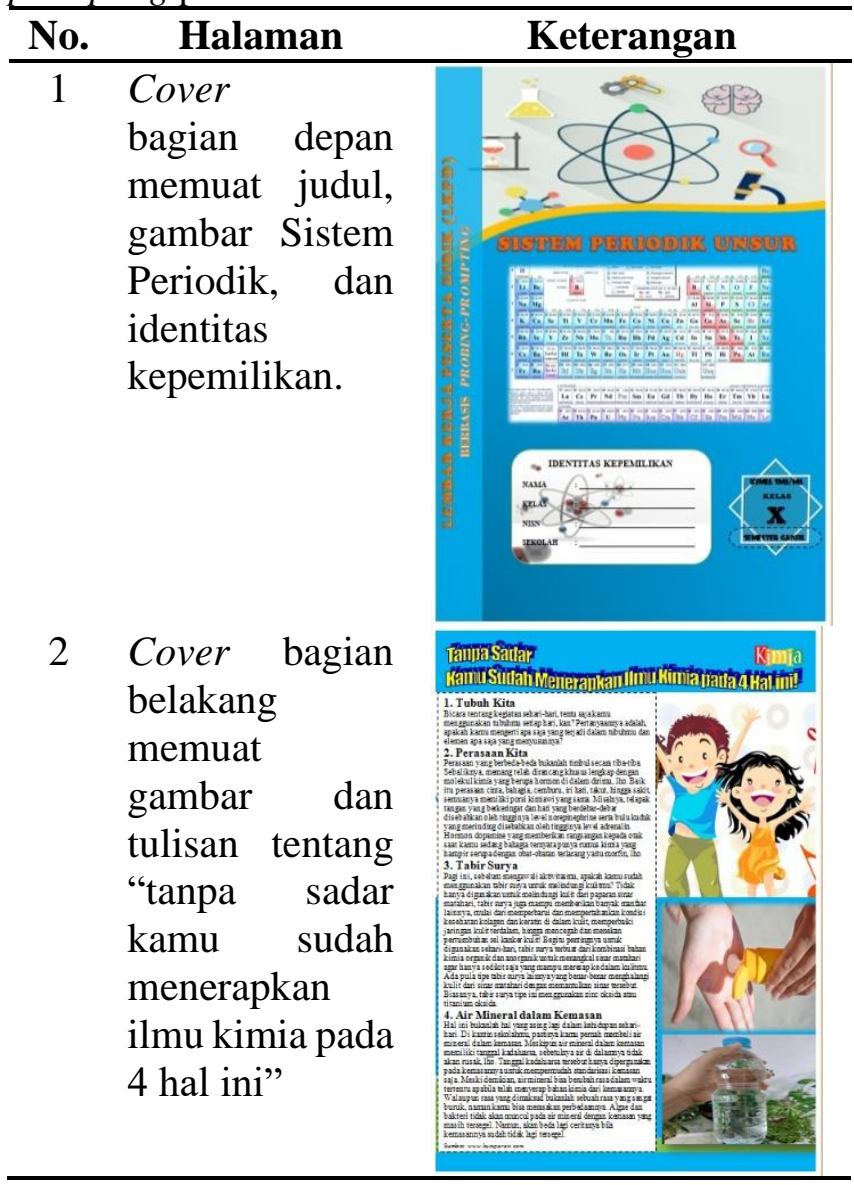

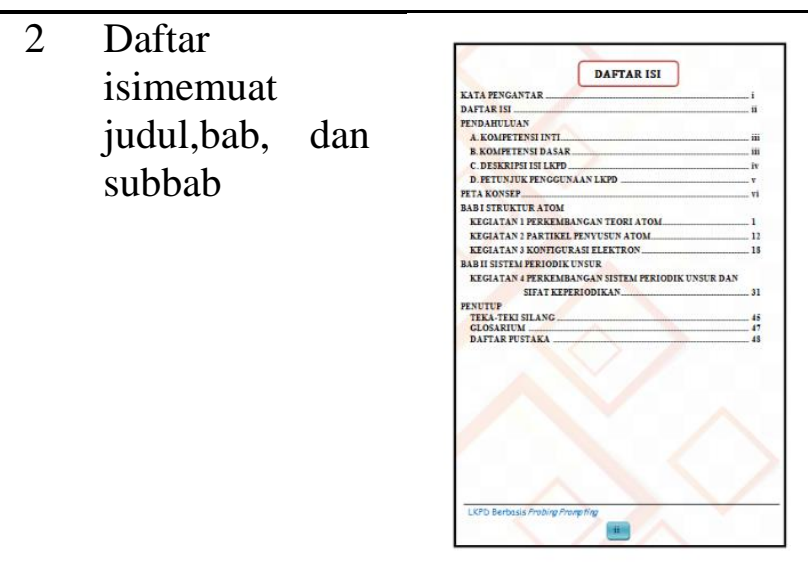

3 Pendahuluan memuat

Deskripsi KI, $\mathrm{KD}$, isi LKPD dan petunjuk penggunaan

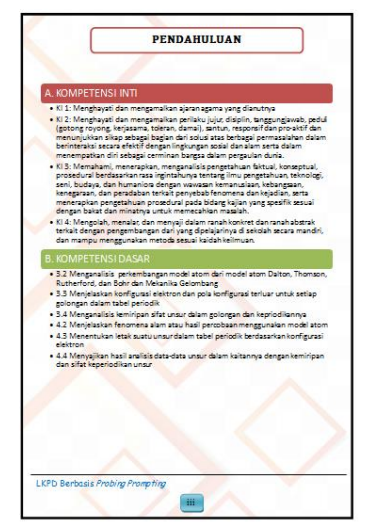

4 Isi memuat judul, bab, dan sub bab yang dibahas.

Terdapat juga indikator dan tujuan serta "tahukah kamu” setiap kegiatan. Serta model probingprompting.

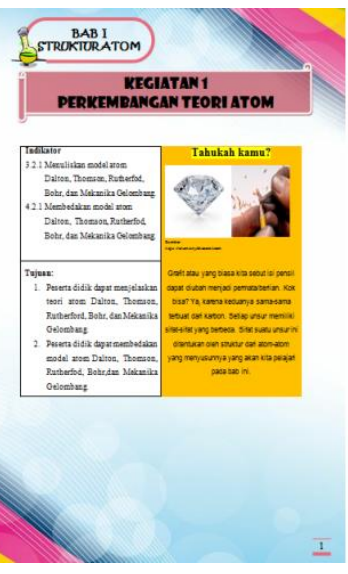

5 Penutup berisikan TTS sebagai evaluasi aktivitas peserta didik

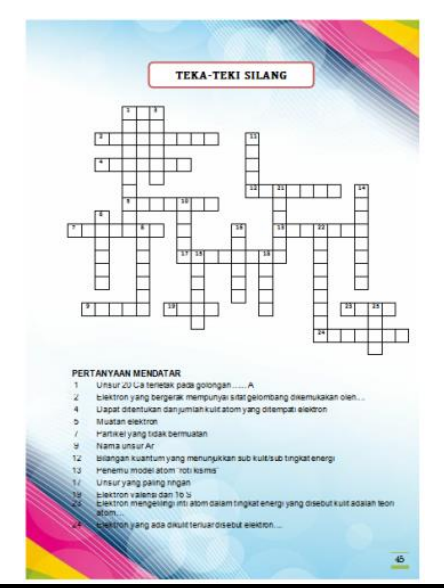




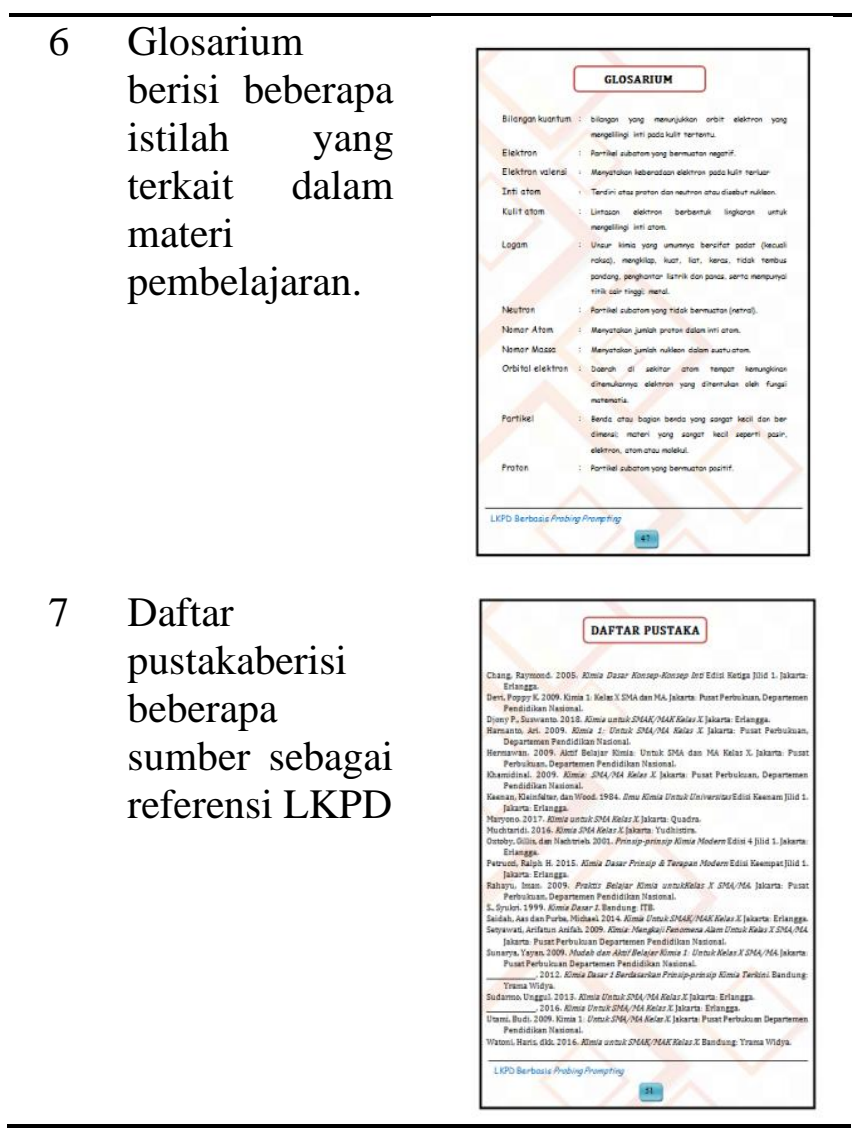

c. Tahap Pengembangan (Develop)

Tujuan tahap ini yaitu untuk menghasilkan perangkat pembelajaran yang sudah direvisi berdasarkan masukkan dari para pakar.

1) Validasi Ahli

Perangkat pembelajaran sebelum diujicobakan kepada peserta didik, dilakukan validasi oleh ahli materi, ahli media dan ahli bahasa. Dari hasil penilaian para ahli ini, kemudian dilakukan perhitungan tingkat validitas LKPD. Uji validitas bertujuan untuk mengevaluasi LKPD yang telah dikembangkan.

\section{a) Ahli Materi}

Ahli materi dalam penelitian ini adalah Bapak Pangoloan Soleman Ritonga, S.Pd., M.Si. Beliau merupakan salah satu dosen Pendidikan Kimia, Fakultas Tarbiyah dan Keguruan, Universitas Syarif Kasim Riau.Lembar penilaian berupa angket yang berisi 16 butir penilaian, mencakup kelayakan isi dan komponen penyajian.

Tabel 6 Saran dan Masukan oleh Ahli Materi

\begin{tabular}{|c|c|c|}
\hline No. & Bagian-bagian & Keterangan \\
\hline 1. & $\begin{array}{l}\text { Referensi perlu } \\
\text { ditambahkan }\end{array}$ & $\begin{array}{l}\text { Sudah } \\
\text { diperbaiki }\end{array}$ \\
\hline 2. & $\begin{array}{l}\text { Substansi KI } 3 \text { dan KD } \\
\text { nya }\end{array}$ & $\begin{array}{l}\text { Sudah } \\
\text { diperbaiki }\end{array}$ \\
\hline 3. & $\begin{array}{l}\text { Penggunaan ilustrasi } \\
\text { kurang tepat }\end{array}$ & $\begin{array}{l}\text { Sudah } \\
\text { diperbaiki }\end{array}$ \\
\hline 4. & $\begin{array}{l}\text { Belum jelas } \\
\text { pendahuluan, isi, dan } \\
\text { penutup }\end{array}$ & $\begin{array}{l}\text { Sudah } \\
\text { diperbaiki }\end{array}$ \\
\hline 5. & $\begin{array}{l}\text { Daftar isi belum } \\
\text { memuat judul, bab, dan } \\
\text { subbab }\end{array}$ & $\begin{array}{l}\text { Sudah } \\
\text { diperbaiki }\end{array}$ \\
\hline
\end{tabular}

b) Ahli Bahasa

Ahli bahasa dalam penelitian ini adalah Bapak Afdhal Kusumanegara, M.Pd.. Beliau merupakan salah satu dosen Pendidikan Bahasa Indonesia, Fakultas Tarbiyah dan Keguruan, Universitas Syarif Kasim Riau. Lembar penilaian berupa angket yang berisi 9 butir penilaian mencakup subkomponen: sesuai dengan peserta didik; komunikatif; dialogis dan interaktif; lugas; koherensi dan keruntutan alur pikir; kesesuaian kaidah bahasa indonesia; dan penggunaan istilah dan simbol/lambang.

Tabel 7 Saran dan Masukan oleh Ahli Bahasa

\begin{tabular}{|c|c|c|}
\hline No. & Bagian-bagian & Keterangan \\
\hline 1. & $\begin{array}{l}\text { Aspek keterbacaan } \\
\text { masih perlu } \\
\text { disempurnakan }\end{array}$ & $\begin{array}{c}\text { Sudah } \\
\text { diperbaiki }\end{array}$ \\
\hline 2. & $\begin{array}{l}\text { Pokok pikiran antar } \\
\text { alinea perlu } \\
\text { dipertautkan }\end{array}$ & $\begin{array}{l}\text { Sudah } \\
\text { diperbaiki }\end{array}$ \\
\hline 3. & $\begin{array}{l}\text { Sesuaikan dengan EYD } \\
\text { dan KBBI }\end{array}$ & $\begin{array}{c}\text { Sudah } \\
\text { diperbaiki }\end{array}$ \\
\hline
\end{tabular}

c) Ahli Media

Ahli media dalam penelitian ini adalah Bapak Bero Usada, S.Kom., MM. Beliau merupakan salah satu dosen di Sekolah Tinggi Manajemen Informatika dan Komputer (STMIK) Dharmapala Riau, Program Studi Sistem Informasi. Lembar penilaian berupa angket yang berisi 13 butir penilaian, mencakup teknik penyajian, pendukung penyajian materi, penyajian pembelajaran, dan kelengkapan penyajian. 
Tabel 8 Saran dan Masukan oleh Ahli Media

\begin{tabular}{clc}
\hline No. & \multicolumn{1}{c}{ Bagian-bagian } & Keterangan \\
\hline 1. & $\begin{array}{l}\text { Diperkaya dengan } \\
\text { gambar/foto realitas }\end{array}$ & $\begin{array}{c}\text { Sudah } \\
\text { diperbaiki } \\
\text { 2udah }\end{array}$ \\
2. & $\begin{array}{l}\text { Bagian } \text { cover depan dan } \\
\text { belakang disesuaikan } \\
\text { untuk menarik perhatian }\end{array}$ & $\begin{array}{c}\text { Superbaiki } \\
\text { diperta didik }\end{array}$ \\
& \\
peserta & Perlu diperbanyak \\
& $\begin{array}{l}\text { warna di bagian peta } \\
\text { konsep dan seluruh } \\
\text { bagian LKPD untuk } \\
\text { kelas X }\end{array}$ & \\
\hline
\end{tabular}

Tabel 9 Perhitungan Data Hasil Uji Validitas Secara Keseluruhan

\begin{tabular}{lcc}
\hline No. & Para Ahli & $\begin{array}{c}\text { Nilai } \\
\text { Validitas }\end{array}$ \\
\hline 1. & Ahli materi & $86.25 \%$ \\
2. & Ahli bahasa & $81.11 \%$ \\
3. & Ahli media & $90.00 \%$ \\
& Rata-rata & $85.78 \%$ \\
\hline
\end{tabular}

Berdasarkan perhitungan tabel 9, jelas terlihat bahwa persentase keseluruhan dari para ahli adalah sangat valid. Karena berada pada rentang $81 \%$ sampai $100 \%$, sehingga LKPD berbasis probingprompting pada materi SPU sudah layak dengan saran dan komentar dari para ahli dijadikan bahan perbaikan dalam menyempurnakan LKPD ini. Berdasarkan hasil analisis penilaian pakar terhadap LKPD dapat dinyatakan bahwa LKPD yang dikembangkan memiliki kualitas yang baik dan dapat diterapkan dalam pembelajaran. Hal ini sejalan dengan penelitian yang dilakukan Wijayanti dkk. bahwa sebelum diimplementasi LKPD yang telah dikembangkan dinilai kualitasnya terlebih dahulu dengan cara meminta penilaian dari tim ahli sehingga diperoleh skor untuk setiap aspek [21].

\section{2) Uji Praktikalitas}

Uji praktikalitas bertujuan untuk mengetahui tingkat kepraktisan LKPD saat digunakan dalam proses pembelajaran. Uji praktikalitas dilakukan dengan memberikan angket kepada tiga orang guru kimia. Adapun guru-guru kimia tersebut meliputi Ibu Iin Fatimah, S.Pd., M.Pd. sebagai guru kimia I,
Zuriani,S.Pd. sebagai guru kimia II, dan Dra Asmiwati, M.Pd sebagai guru kimia III.

Tabel 10 Saran dan Masukan oleh Guru Kimia

\begin{tabular}{ccc}
\hline No. & Bagian-bagian & Keterangan \\
\hline 1. & $\begin{array}{c}\text { Perlu ditambahkan } \\
\text { jumlah soalnya }\end{array}$ & $\begin{array}{c}\text { Sudah } \\
\text { diperbaiki }\end{array}$ \\
\hline
\end{tabular}

Tabel 11 Perhitungan Data Hasil Uji Praktikalitas Secara Keseluruhan

\begin{tabular}{llc}
\hline No. & \multicolumn{1}{c}{ Guru Kimia } & $\begin{array}{c}\text { Nilai } \\
\text { Praktikalitas }\end{array}$ \\
\hline 1. & Iin Fatimah, M.Pd. & $86.00 \%$ \\
2. & Zuriani, S.Pd. & $88.00 \%$ \\
3. & Dra. Asmiwati, M.Pd. & $82.00 \%$ \\
& Rata-rata & $85.33 \%$ \\
\hline
\end{tabular}

Berdasarkan perhitungan tabel 11 , jelas terlihat bahwa persentase keseluruhan oleh guru kimia adalah sangat praktis. Karena berada pada rentang $81 \%$ sampai $100 \%$, sehingga LKPD berbasis probing-prompting pada materi SPU termasuk dalam kriteria sangat praktis dengan saran dan komentar dari para guru dijadikan bahan perbaikan dalam menyempurnakan LKPD ini. Hasil analisis data yang diperoleh dari penilaian guru terhadap LKPD memberikan tanggapan positif. tanggapan positif ini menunjukkan bahwa LKPD berbabis probing-prompting ini layak untuk digunakan dan mudah untuk dipelajari oleh peserta didik. Hal ini sejalan dengan penelitian Marcedes bahwa untuk menilai kelayakan bahan ajar juga dilakukan dengan cara meminta tanggapan dari guru dan hasil tanggapan yang diperoleh adalah positif.

\section{3) Respon Peserta Didik}

Setelah desain LKPD direvisi dan dinyatakan valid serta praktis, maka selanjutkan dapat diuji cobakan untuk mengetahui respon peserta didik. Respon peserta didik dilakukan oleh 10 orang peserta didikkelas X MIA 1 yang dipilih secara acak oleh guru kimia.

Tabel 12 Hasil Respon Peserta Didik

\begin{tabular}{clccc}
\hline No. & & Aspek & Jumlah & \% \\
\hline 1 & Tampilan & a.pengenalan & 1 & $10 \%$ \\
& $\begin{array}{l}\text { yang paling } \\
\text { menarik }\end{array}$ & $\begin{array}{l}\text { diawal bab } \\
\text { b.pertanyaan }\end{array}$ & 2 & $20 \%$ \\
\hline
\end{tabular}




\begin{tabular}{|c|c|c|c|c|}
\hline & & c.ayo tanggapi & 2 & $20 \%$ \\
\hline & & d.cover & 5 & $50 \%$ \\
\hline \multirow[t]{4}{*}{2} & Penyajian & a.desain cover & 5 & $50 \%$ \\
\hline & yang & b.desain isi & 2 & $20 \%$ \\
\hline & menarik & $\begin{array}{l}\text { c.gambar/ } \\
\text { ilustrasi }\end{array}$ & 2 & $20 \%$ \\
\hline & & $\begin{array}{l}\text { d.soal-soal } \\
\text { (evaluasi) }\end{array}$ & 1 & $10 \%$ \\
\hline \multirow[t]{4}{*}{3} & Manfaat & $\begin{array}{l}\text { a. wawasan/ } \\
\text { ilmu } \\
\text { pengetahuan }\end{array}$ & 1 & $10 \%$ \\
\hline & & $\begin{array}{l}\text { b. kesenangan } \\
\text { dalam } \\
\text { membaca }\end{array}$ & 2 & $20 \%$ \\
\hline & & $\begin{array}{l}\text { c.informasi } \\
\text { tambahan }\end{array}$ & 2 & $20 \%$ \\
\hline & & $\begin{array}{l}\text { d.membantu } \\
\text { proses } \\
\text { pembelajaran }\end{array}$ & 5 & $50 \%$ \\
\hline \multirow[t]{3}{*}{4} & $\begin{array}{l}\text { Kemudahan } \\
\text { penggunaan }\end{array}$ & $\begin{array}{l}\text { a.sangat } \\
\text { mudah }\end{array}$ & 8 & $80 \%$ \\
\hline & & $\begin{array}{l}\text { b. cukup } \\
\text { mudah }\end{array}$ & 1 & $10 \%$ \\
\hline & & $\begin{array}{l}\text { c. sedikit } \\
\text { mudah }\end{array}$ & 1 & $10 \%$ \\
\hline \multirow[t]{4}{*}{5} & Tanggapan & $\begin{array}{l}\text { a. sangat } \\
\text { bagus }\end{array}$ & 6 & $60 \%$ \\
\hline & & b. bagus & 1 & $10 \%$ \\
\hline & & c. cukup bagus & 2 & $20 \%$ \\
\hline & & $\begin{array}{l}\text { d. sedikit } \\
\text { bagus }\end{array}$ & 1 & $10 \%$ \\
\hline
\end{tabular}

Dari tabel 12, terlihat bahwa sebagian besar (50\%) peserta didik menyukai/tertarik bagian desain cover dan dapat membantu dalam proses pembelajaran. Dari aspek kemudahan penggunaan diperoleh $80 \%$ sangat memudahkan peserta didik. Kemudian tanggapan peserta didik terhadap LKPD sangat bagus $60 \%$ dan $10 \%$ bagus $(70 \%$ pada kriteria bagus-sangat bagus). Hal ini menandakan bahwa LKPD ini sudah layak untuk dipelajari dan mereka juga tertarik terhadap penggunaan LKPD

\section{Daftar Pustaka}

[1] Yuniyanti ED. Pembelajaran Kimia Menggunakan Inkuiri Terbimbing dengan Media Modul Dan E-Learning Ditinjau dari Kemampuan Pemahaman Membaca dan Kemampuan Berpikir Abstrak (Pembelajaran Kimia Pada Materi Pokok Kesetimbangan Kimia Kelas XI IPA Di dalam pembelajaran system periodik unsur. Hal ini sejalan dengan hasil penelitian Chusni dan Widodo bahwa respon peserta didik terhadap LKPD yang dikembangkan untuk pembelajaran menunjukkan hasil yang baik, sehingga produk ini layak digunakan dalam pembelajaran. Hal ini juga sepadan dengan pendapat dari Tasdelen \& Koseaglu yang mengatakan suatu bahan ajar teks dikatakan baik, apabila mendapat respon positif dari peserta didik terkait aspek kemenarikan (interesting), sejaun mana dapat membantu peserta didik (helpful), bagaimanan kemudahan untuk dipahami oleh peserta didik (understable) [22].

Selain respon positif, ada juga sebagian kecil peserta didik memberikan respon negatif, yakni aspek tampilan $30 \%$ peserta didik tidak menyukai pada bagian pertanyaan dan ayo tanggapi, serta aspek penyajian $40 \%$ peserta didik yang ingin memperbaiki/menambahkan pada bagian soal-soal (evaluasi). Hal ini menjadi bahan pertimbangan peneliti untuk memperbaiki produk yang dihasilkan. Sehingga LKPD yang dihasilkan layak, praktis, dan dapat digunakan oleh peserta didik dalam memahami materi sistem periodik unsur.

\section{Kesimpulan}

Berdasarkan hasil penelitian dan pembahasan, maka dapat diambil beberapa simpulan yaitu :

a) Tingkat validitas LKPD berbasis probingprompting pada materi sistem periodik unsur berdasarkan uji validitas oleh ahli materi, ahli bahasa, dan ahli media sebesar $85.78 \%$ yang termasuk kategori sangat valid.

b) Tingkat praktikalitas LKPD berbasis probingprompting pada materi sistem periodik unsur oleh tiga orang guru kimia sebesar $85.33 \%$ yang termasuk kategori sangat praktis.

SMA Negeri.

[2] Lestari L, Alberida H, Rahmi YL. Validitas dan Praktikalitas Lembar Kerja Peserta Didik (LKPD) Materi Kingdom Plantae Berbasis Pendekatan Saintifik untuk Peserta Didik Kelas X SMA/MA. J Eksakta Pendidik 2018; 2: 170-177. 
[3] Mayasari. Penerapan Teknik ProbingPrompting dalam Pembelajaran Matematika Siswa Kelas VIII MTSN Lubuk Buaya Padang. FMIPA UNP J Pendidik Mat 2014; 3: 57.

[4] Huda M. Model-Model Pengajaran dan Pembelajaran: Isu-Isu Metodis dan Paradigmatis: Pustaka Pelajar.

[5] Devi EK, Mahdian M. Meningkatkan Keaktifan dan Hasil Belajar Siswa Melalui Model Pembelajaran Probing Prompting pada Materi Hidrokarbon Kelas X di SMA PGRI 6 Banjarmasin. Quantum J Inov Pendidik Sains; 6.

[6] Wanarti P. Pengaruh Metode Pembelajaran Tanya Jawab Probing-Prompting Terhadap Hasil Belajar Siswa pada Standar Kompetensi Menerapkan Dasar-Dasar Elektronika Kelas X AV di SMK Negeri 2 Surabaya. J Pendidik Tek Elektro; 3.

[7] Kariani NK, Putra DBKTNGRS, Ardana IK. Model Problem Based Learning Menggunakan Metode Probing-Prompting Berpengaruh Terhadap Hasil Belajar IPA Siswa. Mimb PGSD Undiksha; 2.

[8] Sugiyono. Metode Penelitian Pendidikan. Bandung: Alfabeta, 2014.

[9] Sugiyono M. penelitian \& pengembangan (Research and Development/R\&D). Bandung Penerbit Alf.

[10] Mulyatiningsih E, Nuryanto A. Metode penelitian terapan bidang pendidikan.

[11] BSNP. Achievement motivation, study habits and academic achievement of students at the secondary level. Instrumen Penilaian Buku Teks Pelajaran, http://bsnpindonesia.org/2014/05/28/instrumenpenilaian-buku-teks-pelajaran-tahun-2014/ (2014, accessed 21 March 2019).

[12] Riduwan. Belajar Mudah Penelitian Untuk Guru- Karyawan Dan Peneliti Pemula. Bandung: Alfabeta, 2015.

[13] Munandar H, Yusrizal Y, Mustanir M. Pengembangan Lembar Kerja Peserta Didik (LKPD) berorientasi nilai islami pada materi hidrolisis garam. J Pendidik Sains Indones (Indonesian J Sci Educ 2015; 3: 27-37.

[14] Latifah S. Pengembangan lembar kerja peserta didik (LKPD) berorientasi nilai-nilai agama Islam melalui pendekatan inkuiri terbimbing pada materi suhu dan kalor. $J$ Ilm Pendidik Fis Al-Biruni 2016; 5: 43-51.

[15] Nurichah EF. Pengembangan Lembar Kegiatan Siswa Berbasis Keterampilan Berpikir Kritis pada Materi Keanekaragaman Hayati. BioEdu 2012; 1: 45-49.

[16] Asnaini A. Pengembangan Lkpd Berbasis Pendekatan Scientific Untuk Meningkatkan Hasil Belajar Dan Aktivitas Peserta Didik Pada Materi Larutan Penyangga. Lantanida 2017; 4: 60-71.

[17] Elvandari H, Supardi KI. Penerapan model pembelajaran probing-prompting berbasis active learning untuk meningkatkan ketercapaian kompetensi siswa. J Inov Pendidik Kim; 10.

[18] Darmawan J, Wijayanti K, Sugiarto S. Implementasi Model TPS Dengan Probing Prompting Berbantuan CD Pembelajaran Pada Dimensi Tiga. Kreano, J Mat Kreat 2013; 4: 34-40.

[19] Noverina S, Wiyono K. Pengembangan Rubrik Penilaian Keterampilan dan Sikap Ilmiah Mata Pelajaran Fisika Kurikulum 2013 di Kelas X Sekolah Menengah Atas. $J$ Inov Dan Pembelajaran Fis 2014; 1: 145151.

[20] Tabany T, Badar TI. Mendesain Model Pembelajaran Inovatif, Progresif, dan Kontekstual: Konsep, Landasan, dan Implementasinya pada Kurikulum 2013 (Kurikulum Tematik Integratif/TKI). Jakarta PT Kharisma Putra Utama.

[21] Fitriani F, Hasan MHM, Musri M. Pengembangan Lembar Kegiatan Peserta Didik (LKPD) Berbasis Masalah untuk Meningkatkan Pemahaman Konsep dan Aktivitas Belajar Peserta Didik pada Materi Larutan Penyangga. J Pendidik Sains Indones (Indonesian J Sci Educ; 4.

[22] Febrianti E, Haryani S, Supardi KI. Pengembangan Lembar Kerja Siswa (LKS) Materi Larutan Penyangga Model Problem Based Learning Bermuatan Karakter Untuk Siswa SMA. J Innov Sci Educ; 4. 